\title{
M.Salaschek
}

\section{VIEWING VERTEBRAL ARTERIES BY DUPLEX SCAN: WHAT TO EXPECT}

\author{
Von-Bodelshuingh-KranhenhuLs Schulstr. Ibhenbueren, FRG
}

A b s t r a c l. In vertebral arteries (v.a) most slcneses occur at their urigins. [3llsasound studies with at $7,5 \mathrm{MHz}$ sector duplex-probe are able to reveal the origins in 6.3$68 \%$ of the right, $1 \mathrm{n} 43-62 \%$ of 1 he lete vretebral arteries (men<women). whereas the prevertebral and the inaterans versal parts $C_{5 / 6}-C_{3 / 4}$ are visualized in $70-90 \%$. The meat cumulative fumen of both v.a. increases by age from 6,0 mm age $<30$ ) to 7.9 лा r (age $>80$ ) wilh a clear predo rijnance of the left $v$, a . іл $33 \%$, of llac right $v .1$. in $17 \%$ Hypoplasia of one or bezlh ved. is present is $5,2 \%$. I a sample of 1131 postixnts pestherlogical flndings occurec In $11 \%$ of the vertehral arteries fstenosesi or ocolusions

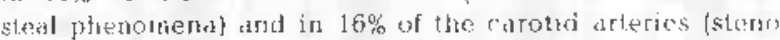
ses $50 \%$ occlusions]. In $12 \%$ of the rases witl infarctions is the vertebro basilar supplical territories pathotugical duplex findings werc preseni, simblary in $20 \%$ of infarc tions in the carotid supplind terribries, auk sn $15 \%$ o vertggo, bul alse in $62 \%$ of patients with peripteral vascu lar disease without nturoloyical signs or symploms versus only in $3 \%$ al control polients of similar age with out resrulenjical or perapheral vastalar disedse

\section{Mrondet:}

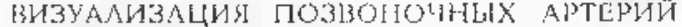

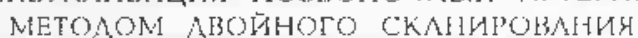

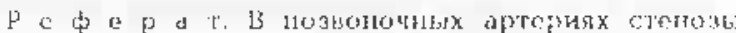

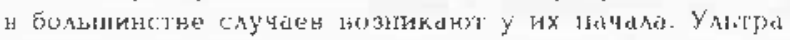

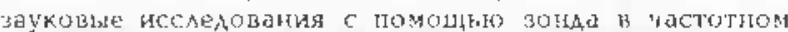

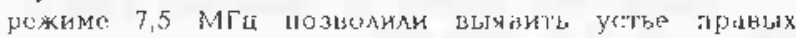

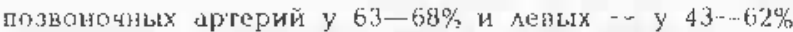

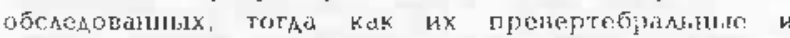

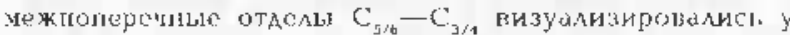

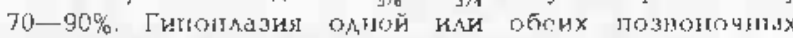

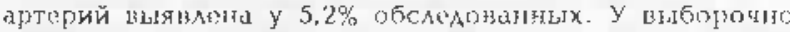

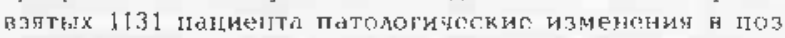
воночных артериях Выянлены в $11 \%$ (СТенозн. окжАн)

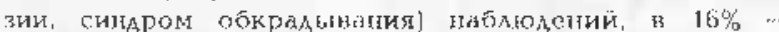
установлены изменения в соннах артериях (стеноз $50 \%$ оккяюзия). В 42\% случаез иинмического инсульта \{ияфаркт) н вертебробазияриом басссйе имели месте Іалологические изменения, ныинленные: методом днои

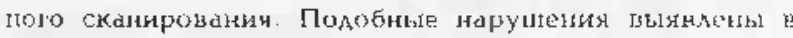
$20 \%$ случаев иІсулыта џ бассейне сопных артерий, в 15\% случаек головокружений. а также у $62 \%$ пациентол с здболеваниями перияејических сосудов без ненро могических синдромон, н талротин, - только у $3 \%$ н коптролыной гуушие здоревьт киц.

\section{Canamex}

УМЫPTКА БАГАНАСН АРТЕРИЯСЕН ИКЕАЕ СКАНИРААУ ЮАЮ ЕЕАОН ВИЗУААИЗАLИЯАЗY (KY3כTY)

Күпчелек очракта умыртка баганась артериялоре

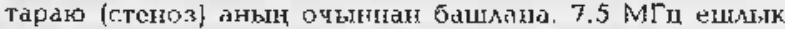

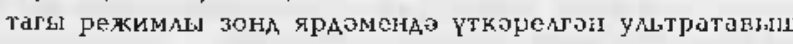
өйранукар тикиерещаннарнец $53-68$ продентянда ун як умыртка артерияләре авызы һом 43-52 иролен тында сул ягын ачыклау мөмкинцеген БирАе. Ә аларіын

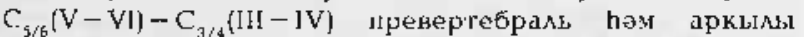
бүлекиаре $70-90$ пропент тикперелгәннарла чагыныш

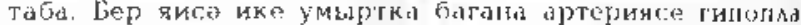

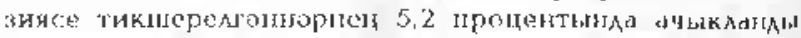

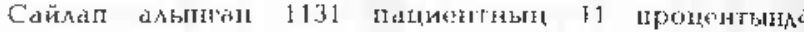

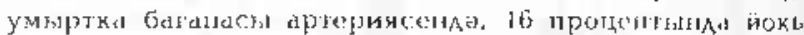

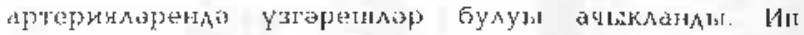

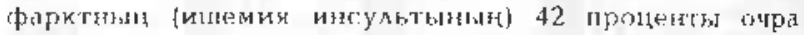

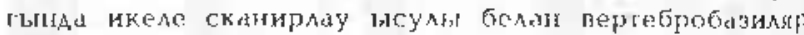

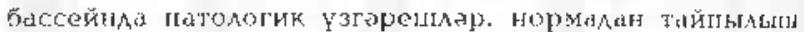

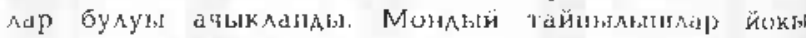

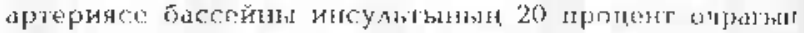

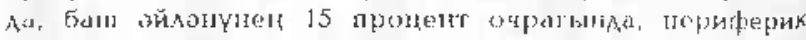

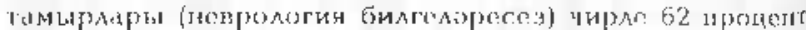

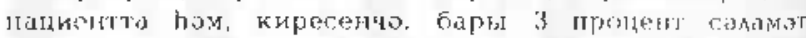

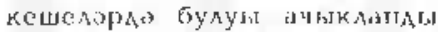

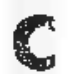
omparing the most likely siles of stenotic lesions in the carolid and the vertotral arte ries, there is one important difference: in the carolid arterios most stenoses occur at the level of the bifurcations, whereas in the vertebral arieries stenoses must be expected mainly at their origins $[3,4]$.

The carotid bilumcations are easily accessibie by uthasound: they are close to the surfiace. their diameter is large, and there is mo bony siructure in the way of the ultrasonic beam. On the other hand, the origins of the vertebral arteries and their prevertebral parts lie decper below the sur lace and, at times, they are already behind the clavicular bones. Therefore the examinition of these parts of the arteries can be difficult, esperi ally when using a rekatively large transducer.

For our investigations Diasonic RA 1 and DRF-300 sector-scanners with 7.5 MHlt duplex probes were used. Distances were calculated by readings between cursor positions; because of an axial resolution of the probes of only $0,3-0,4$ mm, these measurments could only be appro ximations.

\section{NOKMAL. FINDINGS}

Examining 122 successive palients $(61$ male, bi female), the origins of the vertebral asteries were visualized in about $50 \%$ of the men and $65 \%$ of the women … the sex difference probably being the result of the smaller necks most women had. The resi of the prevertebral parts and the further course of the vertebral arteries in the intertransversal spaces $C_{5 / 6}$ and $C_{4 / 5}$ was visible in more than $90 \%$ of the cases; $\mathrm{C}_{3 / 4}$ could be inspected in about 70 to $80 \%$ and $\mathrm{C}_{2 / 3}$ in about 10 to $30 \%$ (fig. 1,2 ). ln only $1,4 \%$ of 1131 patients no part of a vertebral artery could be visualized, either on one or on bolh sides. $\mathrm{Si}$ milar findings were reported by Touboul et al. and Visona et al, $[7,8]$. 


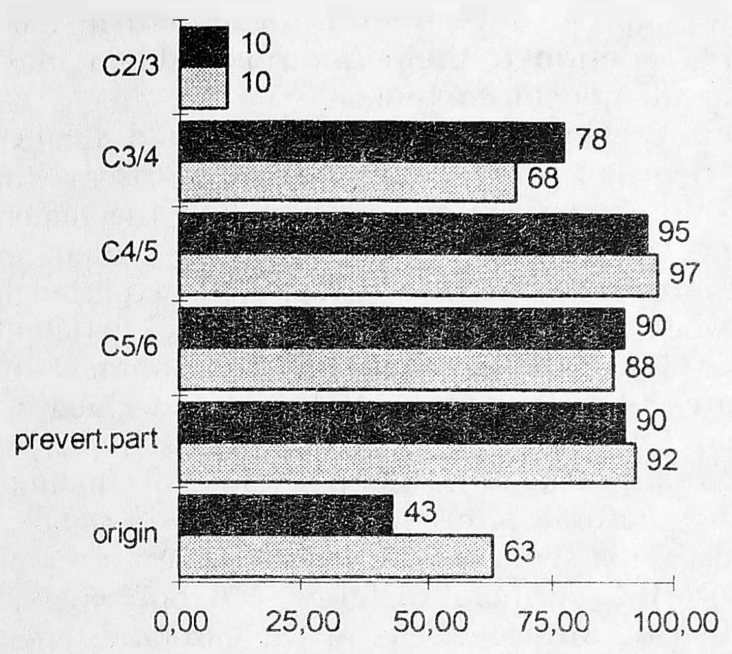

- left vert.a -

$\%$ of all men $(n=61)$

Fig. i. Vertebral arteries. Visibility by duplex-scan. Mate

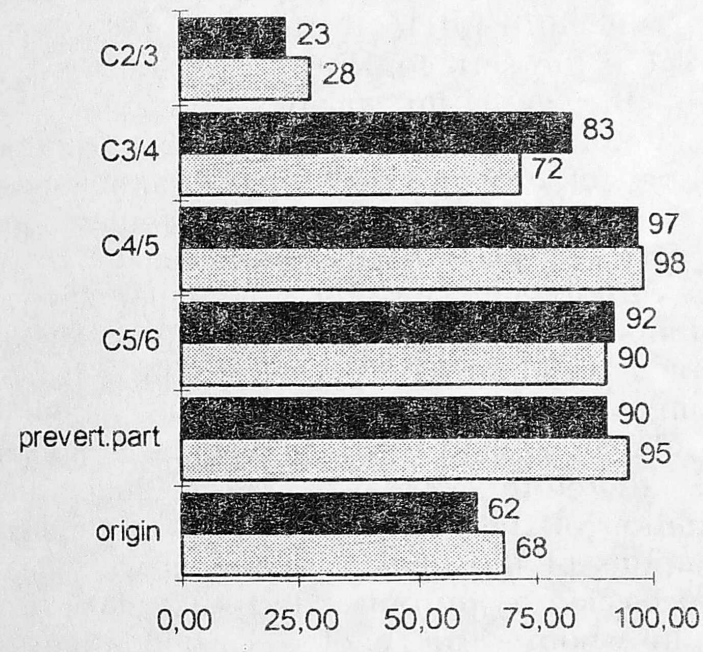

- left vert.a -

$\%$ of all women $(n=61)$

Fig. 2. Vertebral arleries. Visibility by duplex scan. Female

The lumina of the vertebral arteries differ more between right and left than in the carotid arteries. In about one half of 1131 patients the lumina of both vertebral arteries were identical within $0,5 \mathrm{~mm}$. The left artery was dominant in $33 \%$, the right artery in $17 \%$ of the cases. A left/right-difference of more than $1 \mathrm{~mm}$ in lumen was found in $33 \%(24 \%$ 1.r., $9 \%$ r.1.). Hypoplasias (humen equal or less than $1.5 \mathrm{~mm}$ ) were seen in $3,1 \%$ of the right, $1,9 \%$ of the left vertebral arteries: 3 of 1131 patients $\{0,3 \%$ had hypoplasias of both vertebral arteries. The meancumulative lumen of both vertebral arteries increased by age from $6,0 \mathrm{~mm}$ in patients younger than 30 years to $7,9 \mathrm{~mm}$ in patients older than 80 years without a significant sex difference $(+/-1,1 \mathrm{~mm}$ for each agegroup) (fig. 3).

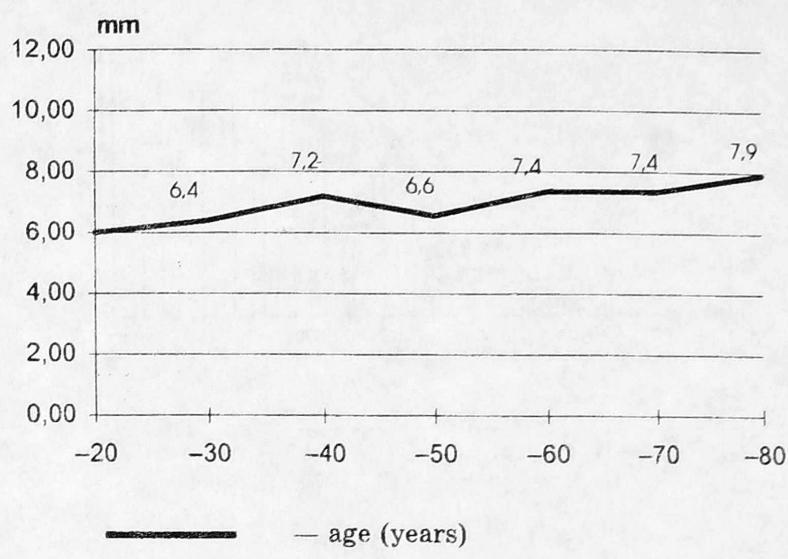

Fig. 3. Cumulative mean lumen of bolh vertebral arteries

\section{PATHOLOGICAL FINDINGS}

Hemodynamically important stenoses of the vertebral arteries were found only at their ori gins. Some plaques were also visuatized in the prevertebral, few in the intertransversal parts. In most cases the degree of stenosis could not be determined, as sufficient B-mode cross-sections were not possible; estimations had to rely on the doppler-signal. For this reason all clearly visible plaques are included under the term "stenosis" in the following data.

Occlusions of vertebral arteries can be difficult to demonstrate, since the diagnosis must rely on a missing doppler signal in several parts of the artery, and reopenings by collateral path. ways cannot always be visualized. Angiography was performed in 4 of our 7 cases, contiming the duplex findings.

Vertebral steal-phenomeno can easily be detected by ultrasound-duplex-scan (table 1).

$$
T \text { a b } \mid \text { e } 1
$$

127 cases of stenoses, occlusions and vertebral steal in 1131 patients

\begin{tabular}{l|c|c|c}
\hline & Stenoses & Occlusions & Vertebr, steal \\
\hline Right vertebr.a & 51 & 3 & 7 \\
Left vertebr.a & 38 & 3 & 11 \\
Both vertebr.a & 13 & 1 & -
\end{tabular}

The percentage of pathological findings in the vertebral arteries increased by age from $3 \%$ in patients in their 4th decade to $16 \%$ in those over 80 years of age. In the same group of patients, carotid stenoses of more than $50 \%$ occured somewhat more frequently in most age groups (fig. 4).

Of all 1131 patients, $16 \%$ had at least one carotid-stenosis of more than $50 \%$, versus $11 \%$ of pathological vertebral findings. Among specific diseases intracranial infarctions in the vertebro-basilar territory and peripheral vascular disease (without neurological signs or symptoms) 


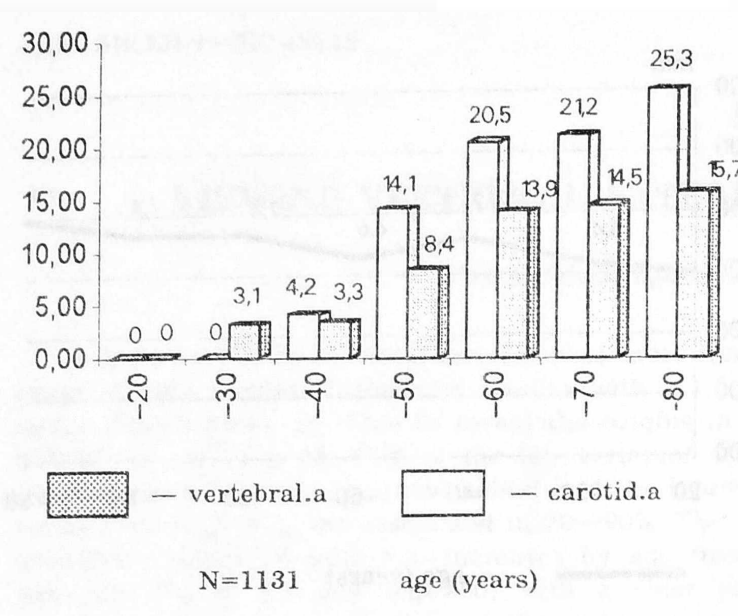

Fig. 4. Vertebral a: steal phenomenze. all stenoses. Carotid a stenosies $>50 \%$

were parlicularly associated with palhological vertebral findings. It is doubtful whether verteb rulhypoplasias are of any diaynostic importance; yet they sem to coincide more frequenlly with cases of infarctions or lransitory disturbances irz the vertebro-tosilar supplied areas of the brain (table 2).

\section{DISCUSSION}

Nericscleotic changes in the verlebral arte ries will rarely lead to surgical inlervenlion; ho wever their presence can influcnce the decision whether to treat carolid stcmoses conservatively or surgically. Although conventional doppler sonography can alredidy reveal many hemody namically significant stenoses at the origins of the vesscls $\{5\}$, duplex-scanning will help to identify the vessels more clearly and to place the sample volume of the pulsed-doppler system right al the area of interest. The nisefulness of this approach has already been described by others $\mid 1,2]$. Our investigation of more than 1000) patients confirmed their findings, adding inte resting diagnostic details.

Our previous studies by uifrasound duplex scan revealed that in $88 \%$ of the cases with a carolid-stenosis of more than half the Iumen on one side, atheromatosis was also present in the conflualateral carotid artery. We expected a somewhat lower coincidence in the vertebral arteries |6|. This assumption was confirmed by the present ultrasound study. We decided to compare the percentage of carotid stenoses of more than $50 \%$ with all pathological findings in the vertebral arteries including non-stenotic placques. This seems to he justified, because? pla ques in the vertebral arteries are not as easy fo detect by till rasound as in the carotid arteries: 13 mode and Doppler signals are more dilficult te interpret. because the arteries lie decper ard are surrounded by bony structures; hence small placues will not be recognized as easily in the vertebral as in the carotid arterios. Cross sections of the verlebral arleries will seldom revel the cxact degree of stenosis. I'laques of low ccho density, even difficult to dislinguish in the ves sels close to the surface, are rare in the duplex sans of the vertebral arteries.

In spite of these restriclions we demonstrated \& ieridency of high proportions of pithological verlebral findings in patients having infarctions of the posterior parts of the brain and in casess of TlA, vertigo and peripheral vascular disease without neurological signs or symptums. Hypo plasia of a vertebral artery (dellined by a lumen $<1.5 \mathrm{~mm})$ was also more frequent in vertebrobasilar infarctions than in other dicgnostic groups.

We therefore propose to include the investigation of the vertebral arteries in duplex examinations of the neck of palients with clear vertebro basilar symptoms, and also in every person in whom surgery of a carotici artery is under consideration.

Pathological duplex-scans of carotids (stenoses $>50 \%$ ), vertebral arteries (all stenoses, steal-effect), and vertebral hypoplasias in several identical diagrostic groups (\% of each diagnostie group)

\begin{tabular}{|c|c|c|c|c|}
\hline & $n$ & $\begin{array}{l}\text { Carotid arteries } \\
\text { stenoses }>50 \%\end{array}$ & $\begin{array}{l}\text { Vertebral arterics } \\
\text { steal, all stenoses }\end{array}$ & $\begin{array}{c}\text { Vertebral } \\
\text { hypoplasias }\end{array}$ \\
\hline All patients & 1131 & If, 2 & 11,2 & $\tilde{\hat{0}}, 3$ \\
\hline Control-pat & 123 & 0,8 & 3,3 & 7,3 \\
\hline Infarction, vert. bas. & 19 & 10,5 & 42,0 & i5, 8 \\
\hline Infarction, carotid & 193 & 31,6 & 9,8 & 4,1 \\
\hline TLA, vert, bas. & 17 & 11,8 & 27,6 & 11,8 \\
\hline TLA, carotid & 70 & 25,7 & 20,0 & 1,4 \\
\hline Visual disturbance & 56 & 17,9 & 10,7 & 1,8 \\
\hline Vertigo & 183 & 14,2 & 15,3 & 7,1 \\
\hline Syncope & 84 & 13,1 & 2,4 & 7,1 \\
\hline Parkinson's disease & 41 & 17,1 & 9,8 & 0,0 \\
\hline Psycho-organic syndrome & 50 & 30,0 & 4,0 & 8,0 \\
\hline Periph. vascular discase & 32 & 50,0 & 62,5 & 6,2 \\
\hline
\end{tabular}




\section{REFERENCES}

I. AckerstaffR.G., Hoeneveldf H. Slowinkowski I.M., MoHT.L. Eikelhoom H.C., Lurtwing f.W. Jltrasuruc duplex scaruiry in arterio-sclerolic disease of the innoministe. subclavian and vertebral artories. A confurative study with angiography //Ultrasound Med. Biol.-1984.-No 10.-P.409-4lk.

2. Baud J.M., Cras C., De Crepy 13. Tricot J.F. Apport die l'achotomographic en temps real dans le bilan de la maladie alheromateuse corvico-encephalique //J. Mal. Vasc. - 1983.№ $8 .-\mathrm{I}^{3} .239-244$.

3. Bostrom K., Greitz T. IJassler O., Lillequist $B$. Stenosis of the vertebral artery at its origin from tles subclavian artery. A radiological and bistological study //Acta Nenrol Sicand1966. - No 42.-P.32--38.

4. Dorfler.f. Ein Beitray zur Frage der lokalisation ner arterioskJerose der gehirngeläse mit besonderer Bericksichtj grung dor arteria carotis interna //Arch. Psychiat. Nervonkr.1935. - No 103. $-5.180-190$.
5. Von Reutern G.M., Clarenbach P. Valeus de I'exploration Doppler des collaterales cervicales el de l'ostium vertewral dars le diefynostic des stenoses el occilusions de lartere verlebrale //Ultrasons. $-1980,-$ № $1 .-5.153-162$.

6. RirkenthacherJ. Nomale und patholoyische Analomie des Himģefässsystems //Giarıshir H. edit. Der l finkreis lauf.Siluttgart, 1972.

7. Touboul P.J., Bousser M. C, LaPlane D., CastaigneP. Dup lex scaulung of normal vertcbral arteries //Stroke.-1986.№ $17 .-[.921-923$.

6. Visona A. Lusiani L., Castellani V., Rounsisvalle G., Bonenome A. Pagnan A. The echo-Doppler (duplex) systern for the delection of vertebral artery occlusive disease: comparison with angiography.-J. [nlrasnund. Med. 1986-1o 5.?. $247-250$

Tocrymas: in 1160

\section{T.Mokrusch}

\section{MAGNETIC RESONANCS IMAGING IN SKELETAL MUSCLE FOLLOWING DENERVATION AND ELECTRICAL STIMULATION}

Hedon-Klinih, Lingen, FRG

$A$ b s t $r$ a $r$ t. Following chronic denervation, MRI evaluation of fast. rabbit muscles reveded it distinc: merease of signal intensity and $T_{2}$ relaxation ture. These? changes were missing or less promounced alter treatment with a new type ol electrical stimulalion, which previousty had proved effeclive in avoiding muscle alrophy. Oni month after denervation, there was a slight increase of signal intensity as well in the stimulated as in the untre aled animals, after two months, however, the mcrease was stalistically significant ondy in the non-slimulated muscles $T$, relaxation lime showed a slight incredse after one? month of therapy, whilo there was in significant increase after ore and two roorths without herapy. After $3--6$ manths of electrical stimulation, there was no increase of $T_{2}$ at all. Tire results indicate 1), that MRl car bes user when monitoring stimuldion effects on denervated mascle, dnd 2), that, for this purpose. $T_{2}$ relaxation tirne is Inore useful than signal intensity.

$$
\text { T. Мокруш: }
$$

\section{ВИЗУААИЗАЦИЯ СКЕАЕТНЫХ MЫLШІ. МЕТОАОМ ЯАЕРНО МАГНИТНОГО РЕЗОНАНСА ПОСАЕ АЕНЕРВАЦИИ \\ И ЭАЕКТРИЧЕСКОЙ СТИМУАЯЦИИ}

$P$ e $\phi$ e $p$ a $T$. Визуалнзация методо ндеріомағнитного резонанса Мышц кролика г. хронической денервацией на фоне голодания нозиолияа обнаружит янное увеличение интенсизности синнала и шремени релаксации $T_{2}$. Эти изменения не наблюдались ияи быня мегее выражены после лечгыия злектростимуля цией, которая ранес оказалась эффектипгой в профи матихе атрофии мышц. "lерез месяқ после Асиерваиии наблодалось небольное возрастание интенсивности cиrнand как у сгимулированывг, так и у нестимуян рованиых животных. Оанако через '2 мег ето возрас. тание было статистически значительгым тољько В сти мулированных мылшцах.
T.Mokpyis

АЕНЕРВАДИЯ ПЭМ ЭАЕКТР СТИМУАЯTОРЫÏHАН (:OIL CKEAET MУСKУАAAPHIH ТЕШ-МАГНИТ TH'БӘНЕШЕ ЫСУАҢ БЕАОН ВИЗУААИЗАЦИЯАӘY \{KYЗวTY, ТИКШЕРY\}

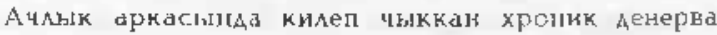
щияле йорт куяны мускулын төш матнит тирбанеше

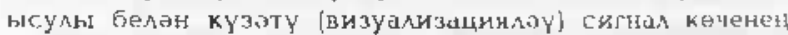
үсүен hом $T_{2}$ релаксация вакыты артулн тапты. Элек

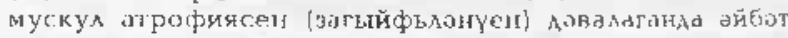
патижаләрга китертол электр стимуяяциясе белан

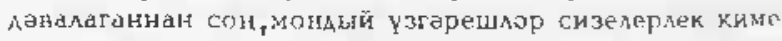
ме ниса бөтенлай қүзтелмаде. Аенервация башланыл. Бер ай узаннан сон, стимуляциялонгын хайњаннарда Аа бимуляцияләнмәган хайнанғарАа ла гиная көченен бсраз үсуе күзатела, Аәкин 2 дйлан үсен бары тик сти муляциялогын мускуларад гынд сая ягьннан сизелер rek була.

Denervation atrophy and electrical stimulation

rate ollowing chronic denervation, a lot of well known changes occur in a skeletal muscle, particularly concetning contractile properties and morphologica] features $[6]$. While contraction force decreases, the muscle fibres become smaller and histologically an increase of fal and connective tissue is found

Despite many investigations during the last decades, the discussion on the efficacy of electro therapy in chronic denervation is still controver sial. In most of the earlier irvestigations, electro therapy was found to delay, but not to avoid 